\title{
Stop, collaborate and listen: Reimagining and Rebuilding the Royal Alberta Museum for Children
}

\author{
Evelyn Delgado*, Jaclyn Kozak**, Natalie Charette***
}

\begin{abstract}
The field of museum education is continually examining and reconsidering how best to engage child audiences, offering child-centered experiences to complement knowledge-rich environments. The implementation of Reggio Emilia approach-based programs and activities, which embrace children's multiple literacies and provide opportunities for free, unstructured play, are best served when complemented by documentation in order to render learning visible to all audiences. It is through documentation that we can actively demonstrate our respect and value for children's learning and play. Play has to be honoured and celebrated in its own right, and the act of documentation needs to be incorporated into daily operations so it becomes a natural part of the museum experience, and a natural part of evaluation practices. The Royal Alberta Museum has recently undergone a large-scale renewal project; staff sought inspiration from these Reggio Emilia-based philosophies in designing a space that will welcome play and value it as learning, reframing the museum educator's role as one that documents, collects and curates children's learning experiences on the gallery floor. In this way, our museum will continue to shape the visitor experience in a ways that place children's contributions at the forefront - in the way that Elee Kirk imagined.
\end{abstract}

Key words: children's museums, play and playfulness, Reggio Emilia, curating children's experiences, documentation

\section{Introduction}

Imagine a museum space full of children playing. What would this look like? What would it sound like? What are the children doing? In 'Hearing and Translating One Hundred Languages in Museums', Elee Kirk urges museum professionals to reimagine the role of children in museums, arguing that museum education is better served by promoting a culture based on listening to, and entering into dialogue with our visitors and each other, in all the languages available to us (2012a: 75).

If we, as museum professionals, have been diligent in offering child-centered experiences, then what is our next step in making those reimaginations a reality? How can we continue to better and enrich our relationships with our visitors, our museum, and with one another? Our answer - one of many - is that museums need to actively demonstrate their respect and value for children's learning through documenting, displaying, and celebrating our audiences' learning processes. Play has to be honoured and celebrated in its own right. Play is learning. 'Play is the work of the child', as stated by educational philosopher Maria Montessori, whose name has become synonymous with the educational philosophy she founded (1973: 4, 9). If play is the work of the child, and we value the work and contributions of children to our society, it is a museum's responsibility to recognize children's work by listening, recording and collecting documentation - and then curating it for display.

At the Royal Alberta Museum we have been privileged to undertake an extensive renewal and rebuild, which has allowed us to reimagine how we will engage children as we move into our new space. This procession of (re)construction has provided us with the opportunity to revisit and renegotiate our approach to early learning (newborn through age nine) drawing 
together philosophies inspired by learning advocates and educational philosophers from across the world. Museum educators need to understand their roles as interpreters, translating and communicating the learning as it happens and ensuring that this learning is made visible. To provide our child visitors with rich, open-ended play opportunities and engage their play-learning, museums need to listen to their youngest audiences. Rather than continuing to discuss what we, as museum educators think should be taught, and seeing the child as an empty receptacle, we need to begin listening to and learning from the children. Documentation is a clear method through which we, as museums, demonstrate that we celebrate, respect and treasure these children's knowledge, their experiences, and their voices. Through sharing the story of our own learning process through our museum's re-development phase as we have strived to build a pedagogical framework for our children's gallery, this article will argue that the best way to honour children and their learning is to engage them as active community members by documenting, collecting, and displaying their work.

\section{Reggio-Emilia: Our Pedagogical Cornerstone}

The process of re-envisioning museums as spaces for children's learning and play has long been underway. Learning advocates - individuals who promote the value of and guide the creation of educational programming in both formal learning environments like schools and informal learning environments like museums, galleries, libraries and other public spaces - have urged museums to provide opportunities for young learners to have hands-on, authentic experiences by giving them the opportunity to manipulate, closely investigate, and explore subjects through multiple literacies. This is not a new concept to the Royal Alberta Museum, nor is it a new trend in museums. In his 1888 book Museums and Art Galleries, Thomas Greenwood, a learning advocate focused on public libraries and galleries, suggested that museums provide children with materials like cardboard and clay in order to explore and respond to the artworks and objects on display in the galleries; he encouraged museums to give children the opportunity to react to their experiences through painting and sculpture, just a few of what the Reggio Emilia philosophy would later call the 'Hundred Languages of Children' (1888: 30). Far more recently, Elee Kirk has advocated for welcoming Reggio-Emilia philosophies in museums, bringing them out of early learning centres and creating a shared language among museum educators, school educators, and children.

Named for the town Reggio Emilia in northern Italy in which it was founded, this learning pedagogy was pioneered by early-learning advocate, Loris Malaguzzi, who described the 100 languages of the child in his poem:

\section{The child}

is made of one hundred

The child has

a hundred languages

a hundred hands

a hundred thoughts

A hundred ways of thinking,

of playing, of speaking (Malagazzi cited in Edwards et al. 1998: 3)

Malagazzi's hundred languages is an accessible metaphor for children's' multiple literacies giving shape to the many ways children choose to express themselves. Understanding that a child-centered pedagogy must first respect, celebrate and empower children's voices - through whichever means of expression they choose - was a core tenet around which Malaguzzi catalyzed his approach to learning. 


\section{Building Children's Museums (and Galleries for Children) in North America}

Museums play an important role in representing, voicing, and recording the stories of societies. The desire to include children in museums was the catalyst for the creation of museum spaces specifically dedicated to children, which began in North America with the opening of the Brooklyn Children's Museum in 1899 (Pascoe, 2013: 216). A veritable boom of children's museums emerged in the United States, seeing the construction of approximately 50 children's museums before the 1930s (Pascoe, 2013: 216). Children's museums provided healthy spaces to learn through play and make meaning through the hundred languages of the child (Pascoe, 2013: 216).

Canada, by comparison, has relatively fewer dedicated Children's Museum spaces - and they were developed at much later dates. The Manitoba Children's Museum opened in 1986 and the children's museum at the Canadian Museum of Civilization, now the Canadian Museum of History, in Gatineau, Quebec followed in 1989 - the same year the UN Convention on the Rights of the Child was produced (McCutcheon 1996: 119). In the near future, our own institution, the Royal Alberta Museum, will join these institutions' ranks with the opening of a purpose-built gallery dedicated to children. The museum has had the tremendous privilege of undergoing a period of renewal and institutional change, and opportunity of moving out from our original

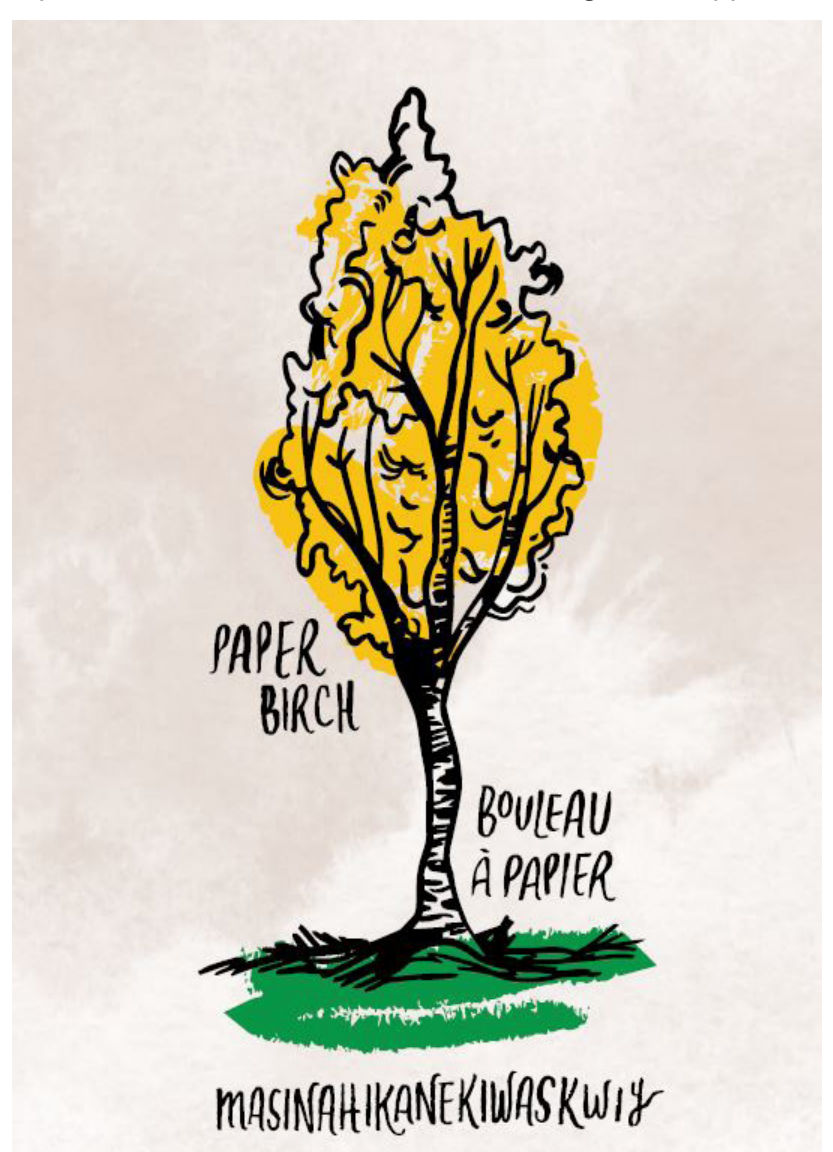

Fig 1. Birch Labels location in the affluent residential neighbourhood of Glenora, and moving to our brand new building in the bustling heart of Edmonton's diverse downtown district. In addition to integrating children's-based programming throughout the Human and Natural History galleries, the museum has allocated a 7,000 square foot space specifically designed as a space for children under the ages of eight, as well as their caregivers and families. The space is designed as an immersive Reggio Emilia-influenced environment, incorporating natural textures and elements relating to the human and natural history of Alberta with the ability to evolve and be responsive to our community. ReggioEmilia philosophy influenced design generally prescribes natural materials and objectrich environments grounded in their local environments and communities (Cannon Design et al. 2010: 19, 67, 97, 127, 147). The Royal Alberta Museum's Children's Gallery was designed to reflect the province's physical and cultural contexts. In the 'Nature's Symphony' interactive exhibit, we replicate sounds from the province's city and natural landscapes: from rustling dried 


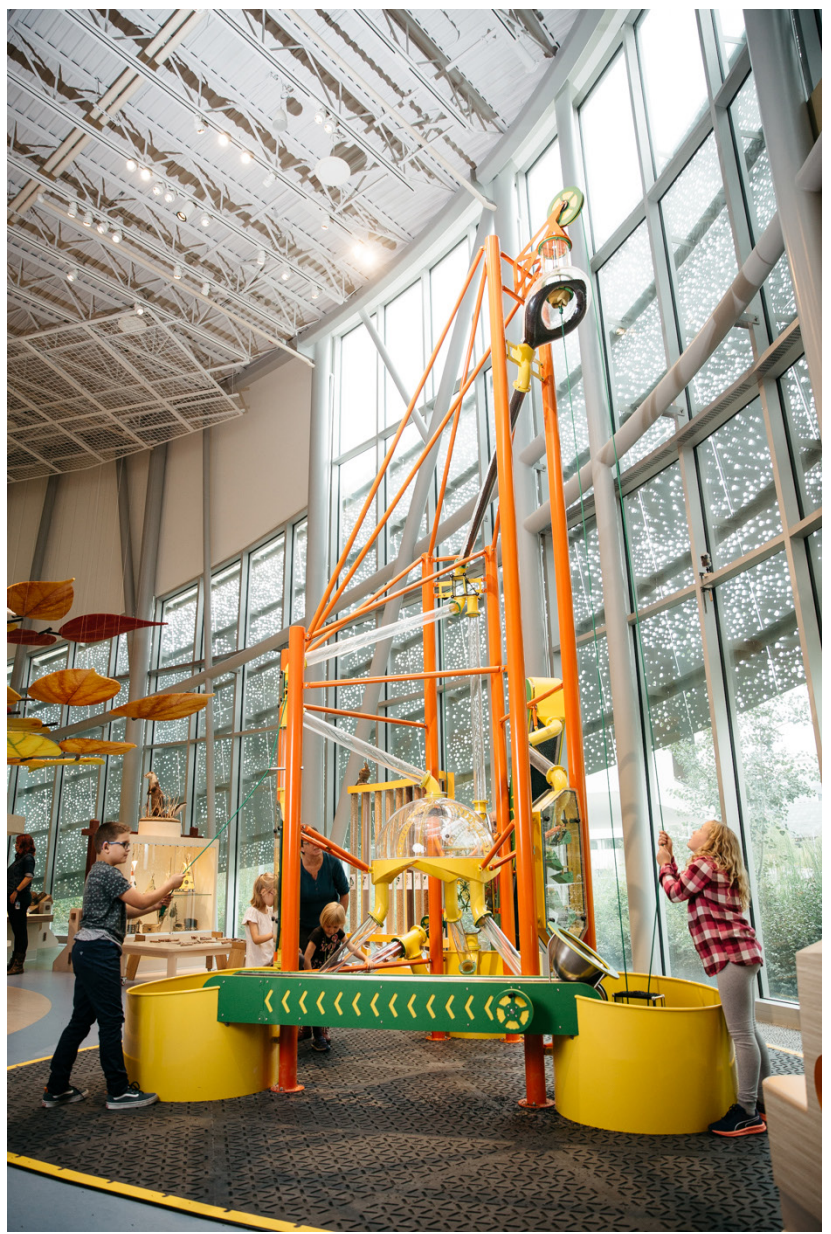

Fig 2. Big Machine

prairie grasses in later summer to bird calls of native species, from the sound of snow ploughs to the local transit system's boarding announcements. We drew the province's mountain landscapes into the cave exhibit and the unique fossil heritage is referenced through the dinosaur-lined 'dig pit' - an exhibit area where children can play as archaeologists and paleontologists, sifting through 'dirt-like' substances to find hidden fossils, rocks and other museum treasures. The gallery's big machine resembles the towering grain-elevators of the farming grasslands. A small forest of local tree specimens is labelled in English, French, and Plains Cree, one of the Indigenous languages of Treaty 6 and the most popularly-spoken First Nations language in the city of Edmonton. Moccasins, made by Dene artists from Northern Alberta, sit alongside baby Converse ${ }^{\mathrm{TM}}$ sneakers in a display case about shoes. The gallery is an embodiment of the physical spaces and cultural landscapes that make up the province of Alberta. It provides children with opportunities to engage each other in play in an environment rich with textures and colours. The development of this space has provided the museum with the opportunity to, in the vein of Elee Kirk's work, reimagine our role within the community and rebuild our understanding of our museum's relationship with children as an informal educational environment. While we have drawn on inspiration broadly from international sources, we are reminded by Gardner that 'no matter how ideal an educational model or system, it is always rooted in local conditions (1998: xviii). The examples provided in Reggio-Emilia based design and programming need to be adapted to fit our own individual context, institutional history, location and audiences.

\section{Places of change, paths of growth: situating our institutional context}

Like most museums, we appreciate the importance of recording the past - including our own institutional history. Understanding our past allows us to contextualize the present and inform our future. Callaghan, Avery and Wien, in their book Documenting Children's Meaning, define context as 'a combination of two aspects in tandem; physical environment and documentation' (2016: 8). As we work towards determining how best to document and display children's learning, we must also work towards documenting our own learning progress as we continue to develop and run our children's gallery space in a way that respects and welcomes children's play and children's voices. 
Offering specialized learning opportunities for children in our museum is not a new reality. However, taking the extra step to document children's learning through pictures, talkback opportunities ${ }^{1}$, and recording observations during testing on a consistent basis has only just started to permeate the work that we do. Since the Royal Alberta Museum first opened its doors in 1967, it has been dedicated to serving its child audiences through exhibits, whether through the animal dioramas of our permanent galleries or through rotating feature exhibits that have appealed to young learners' love of dinosaurs, dragons, bugs, bats, bears, and old-fashioned toys. Later, in the 1980s, the institution opened its 'Discovery Room', a supervised, hands-on and object-packed space in which the museum offered a rotating program of activities and crafts. While exhibits provided children with things to look at, the Discovery Room was intended to give them a space in which they could respond, play, innovate, and generally $d o$. Rather than separating the children from museum objects, the room afforded them a space in which to have tactile experiences within an object-rich environment, albeit by separating children spatially away from the main body of galleries and exhibits.

Play is a vital, inextricable component in the development of a healthy young child - so vital that learning and developmental experts across academic fields have published papers and manuals extensively about the importance of play. This includes the American Academy of Pediatrics publication 'The Importance of play in promoting healthy child development and maintaining strong parent-child bonds' linking play to healthy brain development, the National Association for the Education of Young Children's paper 'Developmentally Appropriate Practice in Early Childhood Programs Serving Children from Birth through Age 8' which named play as a central component in developmentally appropriate educational practices, and finally, and most importantly, the United Nations Convention on the Rights of the Child, which declared play to be a fundamental right of every child (Ginsburg 2007; NAEYC 2009; United Nations Human Rights Council, 1989). The way the Royal Alberta Museum has engaged with young visitors through play, both in the Discovery Room and beyond, has shifted considerably over time. Some of the factors that have informed and shaped these changes include shifting management priorities, funding availability, changes in school curriculum, growth of new diverse audiences, the introduction of admission fares in the 1990s, and, importantly, the shifting preferences and expectations of our visitors. Initially, the Discovery Room served drop-in visitors, including children and their caregivers. In more recent years, however, the room has been dedicated to serving preschool age children through to the second graders for pre-booked curriculum-based programming.

Concurrently with our own institutional change, the province of Alberta is undergoing curriculum redevelopment to be written by the end of $2018 .^{2,3}$ The overhaul of a province-wide curriculum impacts all grade levels from ages five through 18, and serves to complement a recent non-mandatory early learner framework Play, Participation and Possibilities: An Early Learning and Child Care Curriculum Framework for Alberta, published in 2014 through the combined efforts of the Government of Alberta, early childhood centres, and early-childhood and child care university programs from across the province. ${ }^{4}$ Alberta is moving towards a system that places greater emphasis on learning skills such as collaboration, critical thinking, problem-solving, decision-making, lifelong learning, and well-being. This curriculum places greater value on the processes of learning than the products of that learning; this new climate allows students to guide their education based on their own interests, learning styles, and meaning-making processes. Reflective of the 1989 UN Convention on the Rights of the Child, whose principles helped foster an 'attitude of social participation among children [...] so as to prepare them to exercise these rights and become active and responsible citizens,' the new Alberta Curriculum will 'help students achieve their individual potential and create a positive future for themselves, their families and their communities' (United Nations Human Rights Council, 1989). ${ }^{5}$ Furthermore, the new Alberta Curriculum understands that

children strive for intellectual independence. Children are curious and have questions. They want to know why things are the way they are. Children progress through their intellectual growth and develop a reasoning mind that can apply the power of their imaginations. Questions of morality, fairness, mercy and justice fascinate young students as they become more socially oriented and compassionate towards others. ${ }^{6}$ 
The museum is not formally bound by the province's framework, and thus the museum's staff can provide a space that is guided by complementary philosophies but not strictly behold to them (Gandini 1993: 4-8). As Kirk argues, museums and their educators occupy a privileged position in that they are not entirely constrained by curriculum (2012a: 76). Museums are informal learning environments - they differ from the more traditional learning environments of schools. Travelling exhibits, core collections, and current events can all serve as driving forces for curiosity as museums develop - and continually redevelop - their own learning philosophies. While it is important for museums to speak the same language - curriculum - of teachers in schools, museums also need to speak the language of student/early learner/child. Museums have to do better than just speaking to the child through curriculum, but speak the hundred languages of the child. In order to respect the voice of the child, museums must provide children with the space to be loud, to be messy, to explore, and encouraging children to feed their own curiosities.

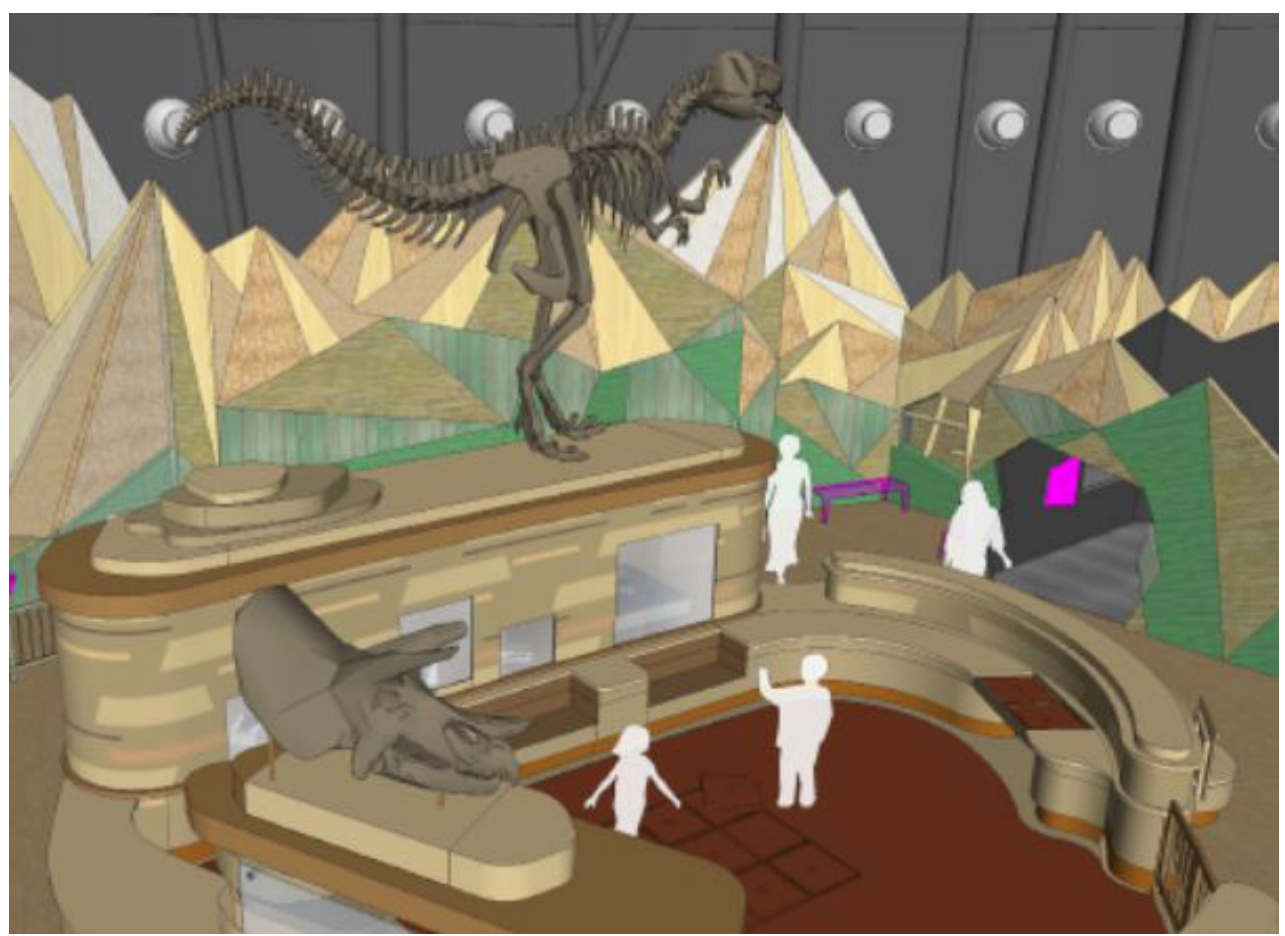

Fig 3. Dig Pit

\section{Respecting the role of children - and play - in museums}

Reggio Emilia positions the environment as yet another 'teacher' (Kirk 2012b: 137). With access to authentic materials, space, diverse audiences, and knowledge-holders, museums are poised as ideal places to fulfill that environmental teaching role. However, their ability to serve as a teacher can be made more difficult by institutional constraints - the relationship between museum staff, visitors and museum objects can be complicated when play is not understood or respected by all members of the museum institution. Simply put, museum staff across all departments must acknowledge that play is learning; it is children's work (Montessori 1973: 4,9 ). Play is active, exploratory, creative, and deeply embedded within children's everyday experiences. Through play, children participate in, learn about, and actively try to make sense of their world and their communities. Through play activities, children collaborate and have complex communications about their social and physical environments, how they are constructed, and how they function. Museums, as places of community gathering and creation, are space that can spark, facilitate and reflect on those multifaceted communications. 
According to the developers of Play, Participation and Possibilities: An Early Learning and Child Care Curriculum Framework for Alberta, play consists of three aspects: imagination and creativity, playful exploration and problem solving, and dizzy play. ${ }^{7}$ Dizzy play refers to the development and learning that occurs when children experiment with chaos and/or disorder. ${ }^{8}$ This type of play, however, is often suppressed in museum spaces, particularly as it often includes 'rough and tumble play, full body exploration, and humour and language play'; it can erupt into 'loud, boisterous, physical bursts' - the kind traditional museum practices sometimes frown upon and discourage.$^{9}$ It demonstrates the contrast between what adult audiences and even museum staff think museum behaviour should look like, and what children need to enact play, experience play, and participate in play in order to learn.

Museums have always been spaces where visitors behaviours are closely monitored: for example, when the British Museum opened in 1769, although admission was free, visitors had to request entrance through an application; this allowed the institutions to restriction access to undesirable visitors (Larkin 2015). In contrast, when the Royal Academy of Arts opened, they charged a fee; attendance became a marker of social class and for creating an atmosphere of a social affair and positioning the Academy as a space to be seen (Larkin 2015).

Museums today continue to control visitors' bodies and behaviours through surveillance, codes of conduct, and physically restricting their movement.

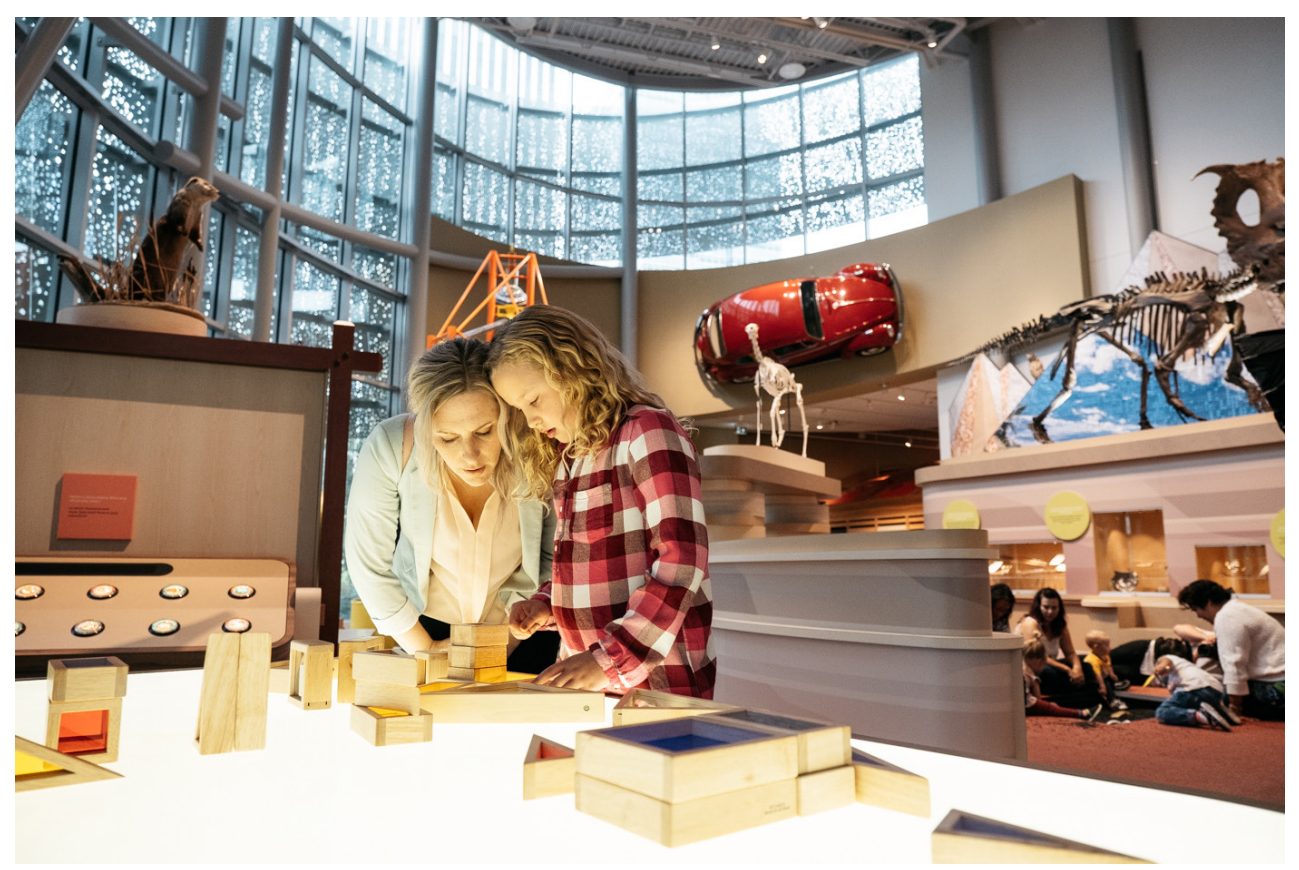

Fig 5 Childrens Gallery.jpg

The Canadian Museum of History (formerly named the National Museum of Canada [19101968], the National Museum of Man [1968-1986] and the Canadian Museum of Civilization [1986-2013]), is a flagship federal museum; one of the most visited museums in the country, it is a precedent-maker within the field of Canadian museology. The Canadian Museum of History presently contains the Canadian Children's Museum and, as such, provides an interesting case-study in the ways in which museums observe and control visitor bodies and movements - particularly those of their child visitors. On their website, the Canadian Museum of History has published a code of conduct that outlines appropriate behaviour for visitors and urges visitors to refrain from shouting and running. ${ }^{10}$ However, on their visitor services page they provide guidance for adult visitors accompanying young children, advising them to 
allow the children to guide them through the exhibits, discuss the things they see and feel, to imagine with their children, and help the child connect the objects they see and activities they do back to their own lives. ${ }^{11}$

In its previous galleries, the Royal Alberta Museum has held with traditional gallery environments, with visitors moving slow and quietly through low-lit exhibit spaces, and the use of security guards rather than interpreters or guides. Through our renewal process, though, we have been afforded the opportunity to challenge our existing practices and re-engage our audiences through providing space for play. This is best exemplified through the development of the child-focused Children's Gallery in which we identified the need to not only welcome, but facilitate and encourage, all types of play in order to best serve our community.

Making space for children is beneficial to the museum institution as a whole. Children can fill the halls and galleries - which can lean towards stark and sterile environments - with joy, discovery, and wonder instead. It is generally understood that intergenerational relationships have a beneficial impact on children by providing children with protection, counselling, guidance and opportunities for development (Zeldin et al. 2005). However those relational exchanges are not one-way; for older adults - particularly seniors' who are at greater risk of social isolation - intergenerational spaces can help increase self-esteem and general well-being and can provide a sense of gratification as a result of their contributions (Morita and Kobayashi 2013: 2). Cross-programming between Toronto's Kipling Acres, a long-term care facility for seniors, and Kipling Early Learning and Child Care Centre, has yielded positive results for seniors, children, and the care facilities' staff. ${ }^{12}$ Seniors were enlivened and invigorated during the activities with the daycare children, helping offset the feelings of isolation often associated with life in nursing home facilities. ${ }^{13}$ Staff reported that, during difficult times, the presence of the children helped alleviate feelings of distress, meanwhile, the children develop broader community bonds, gain knowledge and grow empathy. ${ }^{14}$

In a sampling study of interactive programs with Japanese preschool children and seniors, Morita and Kobayashi found that intergenerational activities resulted in older individuals smiling and conversing more - they were more engaged and more joyful as a result of their participatory interactions with the children.

When older adults are given meaningful roles such as the opportunity to nurture and mentor children, their self-esteem increases in association with feeling needed ... [they] are reminded of their role in society ... In the present study not only responded to children's questions, but also shared knowledge with children by teaching the rules of games and passing on cultural traditions through play (2013: 6).

Simply put, children bring joy. Cultivating spaces that respect play helps invite the rich intergenerational exchanges that help provide visitors of all ages with positive experiences.

Presently, we at the Royal Alberta Museum are working on how best to display our manifesto to inform our new visitors of our new 'rules', which were influenced and developed by artists, learning and developmental experts, caregivers, and children.

Museum staff and adult caregivers have long made assumptions about children's relationships to museums - assumptions that do not always reflect the ways in which children navigate museums spaces or the values and preferences that they, themselves, express. Fisher and colleagues found that parents placed greater value on prescribed and structured play, preferring activities that involved specific goals and outcomes (Fisher et al: 2008). Children, however, placed a higher value on unstructured, exploratory play, which allow children greater freedom to express imagination and creativity (Fisher et al: 2008). The educational outcomes of prescribed play are often more visibly measurable to parents, however, unstructured play, too, presents myriad opportunities for learning. In 'Gaining young children's perspectives on natural history collections', Kirk argued that, too often, museums fail to offer children individualized opportunities for learning (2013: 42). Through her research, Kirk examined how significantly children differ from one another, and how their interests often surprise even their own parents (2014: 211-213).

When children play they have the power; they exert the freedom to learn in their own way, on their own terms and in their own time. Play enables children to engage in the process 
of meaning-making, allowing them to take control of reality to 'decompose and recompose it, and consolidate convergent and divergent thinking' (Rinaldi 2005: 118). They know that when turning the world upside down or inside out, they have the power to restore it. If we, as museum interpreters, understand the power of play then we should allow the space and time for it to develop, while also ensuring the safety of the children, other visitors and the museum itself. At times, this means building stronger connections within our own institutions to help all museum staff value children's play.

As museum educators and interpreters, it is up to us to understand the different languages that 'our colleagues themselves speak' (Kirk 2012: 77), not only so we can translate what they do for visitors, but also to help our colleagues - our curators, conservators, caretakers, security staff, and museum directors - to understand the languages of learning and the importance of giving children the space and opportunities to play. The relationships between museum staff, museum objects, and museum visitors - including children, their caretakers, and community groups - are all complex and diverse; these relationships are at the heart of museums.

When the Chicago Children's museum sought to become a model in early childhood museum education, they embarked on a two-year study to better understand best practices in the field of children's museums (Chicago Children's Museum, Erikson Institute and Gyroscope Inc., 2005: 6). They quickly understood the strong need to make learning visible for two primary reasons. First, to combat notions that play is distinct and separate from learning; they noted that as 'standards-based approaches to education have pushed content goals and testing down to younger and younger ages ... play [has been positioned] as a distraction from learning rather than as one of its most potent forms' (Chicago Children's Museum, Erikson Institute and Gyroscope Inc., 2005: 9). Second, and perhaps more importantly though, the Reggio-Emilia-inspired action of making learning visible activates the process of 'converting [children's] internal discoveries into external artifacts that are visible to themselves and others alike' (Chicago Children's Museum, Erikson Institute and Gyroscope Inc., 20052005: 10).

Making learning visible essentially teaches children how to learn, and in turn teaches all museum staff - museum interpreters, curators, conservators, admissions, security workers and more - the value of children's work, and provides tangible opportunities for evaluation and reflection of best practices in museums for children.

For the Royal Alberta Museum we sought inspiration for our definition of play from Play, Participation and Possibilities: An Early Learning and Childcare Curriculum for Alberta, as well as from the Community-Led Service Philosophy from the Edmonton Public Library. ${ }^{15,16}$ With this local inspiration in hand, we also looked to prominent international children's museums for inspiration, particularly the Chicago Children's Museum Play Manifesto. ${ }^{17}$ With these references in mind, we partnered with local children's author Cathy Beveridge, to write our own play definition to display in the entrance of the gallery as a commitment to our visitors:

Join in the fun. Come on and play

Go in circles or squares - there's no 'right' way.

Let your mind sparkle and your body dance

Go ahead and explore - take a risk, take a chance!

Use real tools to discover and build

Sit and daydream, be amazed and thrilled.

We are creators so let's all design

Grown ups too; don't get left behind

Be a scientist, storyteller, farmer or bear

Play with the wind. Imagine and share.

Let's get going, get messy, and inspired

It's okay to get dirty, silly or tired. 
Museum \& Society, 16 (3) Elaine Bates: Can natural history collections support a connection to na $\$ 91$ for young children and families?

\section{We'll learn and grow in our own way}

As we discover the wonders of play

Provided in both Canadian official languages - French and English - this is our institutional call to play and, moreover, to respect the power of play and revel in its power for empowerment and learning.

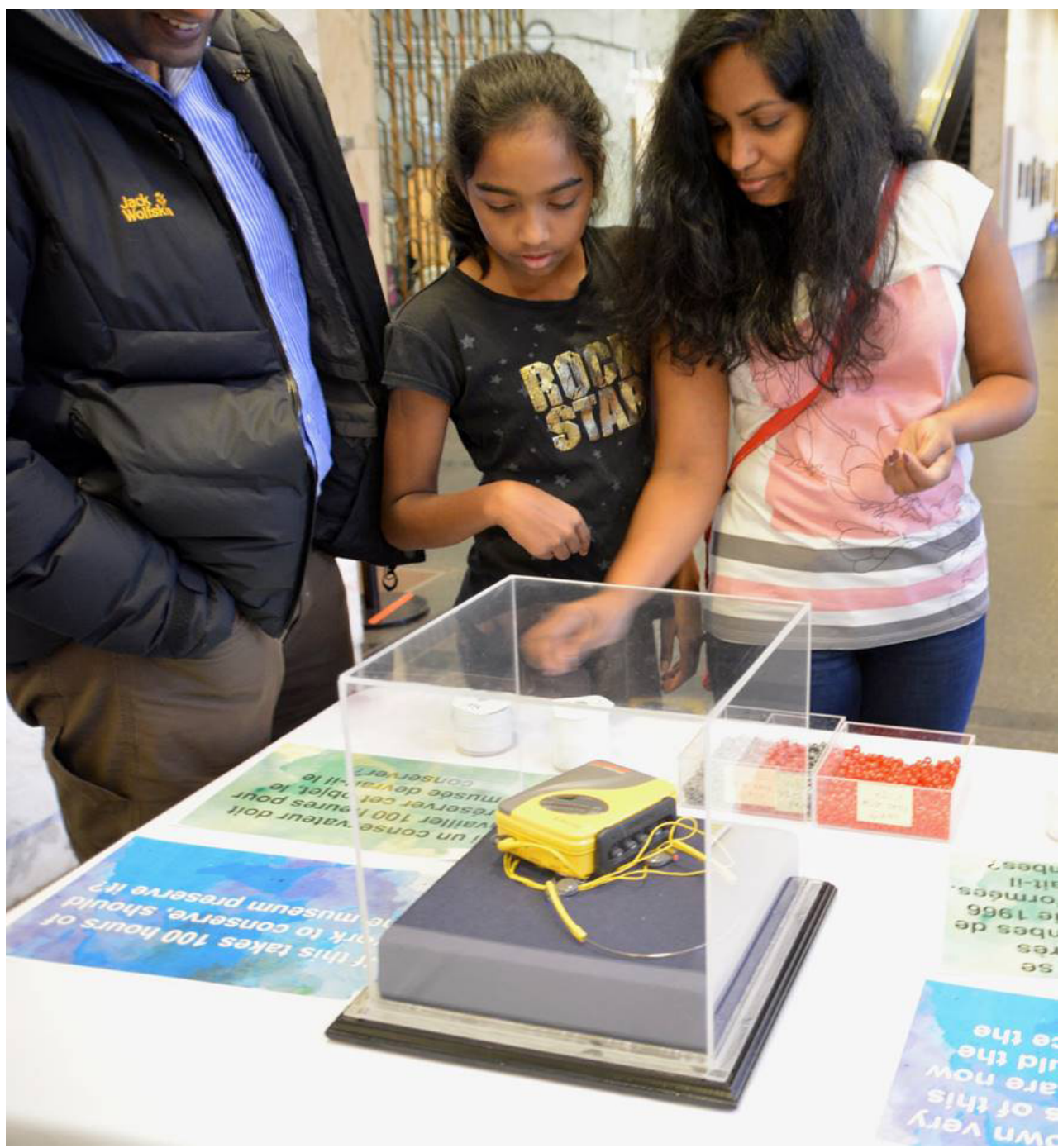

Fig 4. Walkman Talkback

\section{Documentation as the foundation for relationships}

The National Association for the Education of Young Children advocates that teachers document learning for four primary reasons: it shows accountability, it provides opportunity for assessment, it can be used to extend learning, and it allows teachers to reflect on their practice (2009). These benefits remain true even in a museum context, in which children's visits are far more sporadic and the learning is more abstract and self-guided. Documentation - both 
its creation and its curation - is an essential means of dialogue between an institution and its audiences. This documentation can come in many different forms - photographing visitors on the floor, collecting and displaying their art or other products, posing open-ended questions and allowing them the space and materials to respond to it using the hundred languages of the child. Two such important means of generating documentation are talk-back features and open-ended challenges.

Organizations can facilitate documentation within galleries through 'talk-back' opportunities. Talk-back opportunities, as described by Simon, are spaces in which museum visitors can engage in conversations or respond to prompts and questions through design techniques that aim to 'create successful visitor dialogue experiences'. ${ }^{18}$ Participants are encouraged to respond to a prompt through writing, drawing, or even audio and video recordings. Talkbacks serve as temporary platforms that provide the museums visitors opportunities to participate, reflect, evaluate and have their say in museum galleries. For instance, at a weekend family event, learning staff set out a 1980s Walkman and asked adult and children visitors to 'vote' with different coloured beads on whether or not they'd recommend the museum's conservation staff spend 100 hours to preserve it. Adults were more likely to want to see the Walkman conserved, while children were slightly less interested in seeing spending such a large volume of man-hours on its preservation.

Simon, in her reflection on the five year anniversary of her Participatory Museum, asserts that 'humans are the best agents of participation' and that 'participation is political'..$^{19}$ Talkbacks provide visitors with a greater sense of agency - a stronger voice within museum institutions that allows them to guide understanding and shape exhibits and programs. Museums have long understood their role to be transmitters of knowledge - giving voice to artefacts and giving shape to history and then, in turn, teaching those 'facts' to their audience. Visitors were receptacles for the knowledge we, as museum staff, have curated for them. Talkback opportunities allow for dissenting or marginalized voices, histories and perspectives to have a defined space within our institution; they allow museums to stop talking and begin listening. It gives children the opportunity to inject their voices into the conversation - and brings life and colour to the museum space

Museums have tremendous responsibility for representing history and sharing the stories of society - and this must include representing and sharing the stories of children. Museums must be encouraged to record, document, collect and display the products of children's playlearning in order to honour their voices and their knowledge.

Just as curation and design are important to museum exhibits, so too are talk-back platforms which must be carefully developed, monitored and cared for by staff. In this way, museum educators who are documenting visitors and their learning, in turn, become curators. Museums, institutionally, place a high value on documentation; the skillsets applied methodically to the care of collections or the production of new research can be adapted to fit with the needs of documenting museum learning. It is vital to consider the design and wording of the prompt to instigate the direction of documentation. Museums can ask visitors questions and find inventive ways through design to display visitor's responses. They create challenge-based activities for visitors to explore, and photograph visitors discovering and learning from one another. Challenge-based activities are currently considered to be among the main innovative approach to science and technology in schools (Hasni et al. 2016). This educational pedagogy of experimentation and exploration is frequently espoused in science centres in the form of open-ended challenges that encourage visitors to try out new skills and think in new ways: San Francisco's Exploratorium boasts a tinkering studio and the Ontario Science Centre houses an Inventorium, both of which engage visitors with open-ended, hands-on activities. Similarly, our new gallery contains a Maker's Space for children to play and learn through sculpting, building, painting, and creating with real tools and their own two hands.

Documenting visitors, for instance through taking photographs of visitors in action as they respond to the challenge prompt and displaying them in close proximity to the challenge instructions, can help inspire new visitors to approach the challenge, building on the learning of previous visitors, or helping a child further their learning from a previous attempt.

Documentation links visitors through time by recording and celebrating 'fragile moments of learning' (Avery et al. 2016: 1). Williams (2011) argues that educators can use documentation 
to demonstrate to students how their own learning works; documentation and displays helps make children's learning visible to not only adult audiences but also to the child themselves. It engages children with the process of understanding their own learning. Ausubel suggests that one of the most influential contributors to education is what the learner already knows their foundation of knowledge upon which they build - and that teachers need to focus on their students' existing wisdom and teach accordingly (1968: 3). Documenting child visitors' learning helps them visualize and understand their learning and, further, helps museum staff better understand how to facilitate programming that best augments their visitors' existing knowledge and skills. It demonstrates to children that they have a place in the museum environment and that their play and learning is valued. Staff engage in child-led investigations and exercises rather than distract them with close-ended, prescribed, 'keep them occupied' crafts or silly projects. These mindless busy-making exercises can, at times, show that museum staff see them as silly entities that need to be minded, rather than developing, creative, explorative minds that are valuable in their own right. Through provocative museum activities and the documentation that comes from them, children are drawn into dialogue with the inner thought process of visits and are actively using this information for the betterment of the museum environment as a whole. Any time that learning is made visible, there is an opportunity to begin to gain a fuller understanding of children's thought processes and abilities. And through this understanding, museums can create their own unique, reflexive curriculum based on the observations and responses of the children interacting with our space and our objects. Through the creation - and use - of this documentation we, as museum staff, are demonstrating that we are listening to our community.

Our children's gallery must actively collect and exhibit the work of children alongside significant objects and stories in the museum. We share in our museum's mandate to collect, care for, and share objects that embody knowledge. The objects that we collect become artefacts, demonstrating the ideas and explorations of our visitors, articulating the valuable interactions our visitors have fostered in our space and the powerful learning journeys they've undertaken. They become prompts for future learning - for the creator and for others who witness their artefacts in our space.

It is the role of the children's museum to collect objects that express children's voices and stories; documentation is the missing piece that creates opportunities for visitors' individualized learning. It is the method through which museum educators can communicate the colourful languages of children, their thought process, and theorize about the reasoning behind their actions. The process of documentation makes learning visible.

\section{Conclusions}

By facilitating meaningful relationships between staff, visitors and spaces, museums can become a locus where children's learning is celebrated. The creation of documentation and its subsequent display in our space is one aspect through which museums visually demonstrate their commitment to engage in a two-way dialogue with visitors. This process of documentation is an essential tool in the development of community connections but it also plays a significant role in the assessment and extension of learning. Museums render children's learning visible through this process of documentation, providing parents with opportunities to see, value, and even engage in those unstructured play-learning opportunities.

While Elee Kirk argued that we need to learn how to listen to the multiple languages of visitors, documentation may prove to be the key to helping museums 'sustain a meaningful dialogue between the people involved' (Kirk 2012a: 77). Documentation allows visitors and museum staff to learn from, and amongst, each other. Respecting, interpreting, listening to the hundred languages of visitors, and making these languages visible through documentation helps allow our audiences' learning to transcend time and help museums surround themselves with vital, vibrant communities with bright futures. Just as museum exhibits translate information from researchers and curators, so too should museum interpreters translate children's learning into displays of documentation in order to honour these intangible, fleeting moments of visible learning. 
Museums are readily renegotiating their role as institutions of learning, moving away from a one-sided transfer of information from museum staff to our audience and, instead, embracing pedagogies that bring this community of employees and users together in play and dialogue. Essential to this process is a re-alignment amongst staff at all levels and within all departments to understand, value and engage in play. In order to provide children with a healthy and engaging space to learn and play, we must demonstrate that we value our youngest visitors, celebrating their learning and helping others - adult visitors and staff alike - understand the importance of play to development. Like others museum institutions, our children's museums must work to collect and display children's stories. This melds together our roles as an informal education space, a place to collect and share stories, and a house of play and fun. By creating room within the museum institution for children's voices, alongside artists and precious specimens and relics of historic figures, we ensure that our community of staff and visitors - adult and child alike - understand the importance of children's learning and play.

Received: 14 June 2018

Finally Accepted: 25 October 2018

\section{Acknowledgement}

Images courtesy of Royal Alberta Museum

\section{Notes}

1 A talkback opportunity is an activity in which the museum prompts visitors to respond to a challenge or question. It can be as broad as an open-ended question or a simple as a 'yes or no' prompt. When closing the galleries at our former location in Glenora, we offered a talkback opportunity where visitors were asked about their memories of the museum and given paper, markers and pens to write, draw and animate their responses.

2 'Albertaupdating curriculumto betterpreparestudentsforfuturesuccess', Government ofAlberta 2016. https://www.alberta.ca/release.cfm?xID=429254F30CF8B-FC567936-ADA544AE037D475C, accessed 30 November 2017

3 L. Makovichuk, J. Hewes, P. Lirette, and N. Thomas 'Play, Participation, and Possibilities: An Early Learning and Child Care Curriculum Framework for Alberta', Childcare Framework 2014. http://childcareframework.com/jeu participation et possibilites/, accessed 1 September 2017.

4 L. Makovichuk, J. Hewes, P. Lirette, and N. Thomas 'Play, Participation, and Possibilities: An Early Learning and Child Care Curriculum Framework for Alberta', Childcare Framework 2014. http://childcareframework.com/jeu_participation_et possibilites/, accessed 1 September 2017.

5 'What is Curriculum', Government of Alberta $2017 \mathrm{https}$ ://education.alberta.ca/ curriculum-development/what-is-curriculum/ accessed 30 November 2017

6 'The Guiding Framework for the Design and Development of Kindergarten to Grade 12 Provincial Curriculum (Programs of Study), Government of Alberta 2016 https:// education.alberta.ca/media/3575996/curriculum-development-guiding-framework. pdf, accessed 30 November 2017

7 L. Makovichuk, J. Hewes, P. Lirette, and N. Thomas 'Play, Participation, and Possibilities: An Early Learning and Child Care Curriculum Framework for Alberta', Childcare Framework 2014. http://childcareframework.com/jeu_participation_et possibilites/, accessed 1 September 2017. 
8 L. Makovichuk, J. Hewes, P. Lirette, and N. Thomas 'Play, Participation, and Possibilities: An Early Learning and Child Care Curriculum Framework for Alberta', Childcare Framework 2014. http://childcareframework.com/jeu_participation_et possibilites/, accessed 1 September 2017.

9 L. Makovichuk, J. Hewes, P. Lirette, and N. Thomas 'Play, Participation, and Possibilities: An Early Learning and Child Care Curriculum Framework for Alberta', Childcare Framework 2014. http://childcareframework.com/jeu participation et possibilites/, accessed 1 September 2017.

10 'Visitor Code of Conduct' Canadian Museum of History http://www.historymuseum. ca/visit/\#tabs accessed 30 November 2017

11 'Visitor Information' Canadian Museum of History http://www.historymuseum.ca/ visit/ accessed 30 November 2017-12-02

12 Laurie Monsebraaten, 'Magic abounds when daycare, seniors home share roof' February 9 2016 https://www.thestar.com/news/gta/2016/02/09/magic-abounds-when-daycare-seniorshome-share-roof.html accessed February 12018

13 Ibid.

14 Ibid.

15 L. Makovichuk, J. Hewes, P. Lirette, and N. Thomas 'Play, Participation, and Possibilities: An Early Learning and Child Care Curriculum Framework for Alberta', Childcare Framework 2014. http://childcareframework.com/jeu_participation_et possibilites/, accessed 1 September 2017.

16 Community-Led:Aguide for EPLStaff' Edmonton Public Library https://epl.bibliocms. com/wp-content/uploads/sites/18/2015/08/EPL-Community-Led-Booklet-FinalWeb.pdf, accessed 30 November 2017.

17 'Our Manifesto' Chicago Children's Museum http://www.chicagochildrensmuseum. org/Play Manifesto/PlayManifesto FullSize.html, accessed 30 November 2017.

18 Nina Simon, 'Designing Talkback Platforms for Different Dialogic Goals' Museums 2.025 August 2009 http://museumtwo.blogspot.ca/2009/08/designing-talkbackplatforms-for.html accessed 30 November 2017.

$19 \quad$ Nina Simon 'The Participatory Museum, Five Years Later' Museums 2.04 March 2015 http://museumtwo.blogspot.ca/2015/03/the-participatory-museum-fiveyears.html accessed 30 November 2017.

\section{References}

Ausubel, D. (1968) Educational Psychology: a Cognitive View, New York: Holt, Rinehart and Winston, Inc.

Avery, J., Callaghan, K., and Wien, C.A (2016) Documenting Children's Meaning: Engaging in Design and Creativity with Children and Families, Worcester: Davis Publications Inc. 
Cannon Design, VS Furniture, and Bruce Mau Design (2010) The Third Teacher, New York: Abrams.

Fisher, K. R., Hirsh-Pasek, K., Golinkoff, R. M., and Gryfe, S. G. (2008) 'Conceptual split? Parents' and experts' perceptions of play in the 21st century', Journal of Applied Developmental Psychology, 29 (4) 305-316.

Gandini, L. (1993) 'Fundamentals of the Reggio Emilia approach to early childhood education' Young Children, 49 (1), 4-8.

Gardner, H., 'Forward: Complementary Perspectives on Reggio Emilia' in Edwards, C., Gandini, L., and Forman, G. (eds) (1998) The Hundred Languages of the Child: The Reggio Emilia Approach - Advanced Reflections, xv-xviii, London: Ablex Publishing Corporation.

Ginsburg, K. Committee on Communications, and the Committee on Psychosocial Aspects of Child and Family Health (2007) 'The Importance of play in promoting healthy child development and maintaining strong parent-child bonds' Pediatrics 119 (1) http:// pediatrics.aappublications.org/content/119/1/182

Greenwood, T. (1888) Museums and Art Galleries, London: Simpkin, Marshall and Co.

Hasni, A., Bousadra, F., Belletête, V., Benabdallah, A., Nicole, M.-C., Dumais, N., (2016) 'Trends in research on project-based science and technology teaching and learning at K-12 levels: a systemic review', Studies in Science Education 52 (2) 199-231 http://www.tandfonline.com/doi/abs/10.1080/03057267.2016.1226573

Kirk, E. (2012a) 'Speaking, hearing and translating One Hundred Languages in museums', in Jelavić, Ż. (ed.), Old Questions, New Answers: Quality Criteria for Museum Education, 73-80, Zagreb: ICOM Croatia.

(2012b) 'A school trip for Reggio Emilia: enhancing child-led creativity in museums', in Jacobs, R. (ed.), Creative Engagements with Children: International Perspectives and Contexts, 133-41, ebook. Oxford: ID-press.

(2013) 'Gaining young children's perspectives on natural history collections', Journal of Natural Science Collections $138-43$.

Larkin, J. 'The Body in the Museum' Journal of Conservation and Museum Studies 13(1) https://www.jcms-journal.com/articles/10.5334/jcms.1021219.

Malaguzzi, L., 'No Way, the Hundred is there' translated by Lella Gandini, in Edwards, C., Gandini, L., and Forman, G. (eds) (1998) The Hundred Languages of the Child: The Reggio Emilia Approach - Advanced Reflections, 3, London: Ablex Publishing Corporation.

McCutcheon, J. (1996) 'Finding a Space for Children and Their History: The Manitoba Children's Museum and the Children's Museum, Canadian Museum of Civilization', Material History Review, 44 119-122. https://journals.lib.unb.ca/index.php/MCR/ article/view/17715/18990

Montessori, M. (1973) 'Child's Instinct to Work', Association Montessori Internationale Journal.

Morita, K., and Kobayashi, M., (2013) 'Interactive programs with preschool children bring smiles and conversation to older adults: time-sampling study' BMC Geriatrics 13, 111. 
National Association for the Education of Young Children (2009), Developmentally Appropriate Practice in Early Childhood Programs Serving Children from Birth through Age 8 Position Paper, Washington: NAEYC 1-31.

Pascoe, C. (2013) 'Putting away the things of childhood: museum representations of children's cultural heritage' in Kate Darian Smith and Carla Pascoe (ed) Children, Childhood and Cultural Heritage, 209-221, New York: Routledge.

Rinaldi, C. (2001) Making Learning Visible: Children as Individual and Group Learners, Oxon: Routledge.

(2005) In Dialogue with Reggio Emilia: Listening, researching and learning New York: Routledge.

United Nations Human Rights Council. (1989). Convention on the Rights of the Child.

William, D. (2011). 'What is assessment for learning' Studies in Educational Evaluation, 37 3-14.

Zeldin, S., Larson, R., Camino, L., and O'Connor, C., (2005) 'Intergenerational

Relationships and Partnerships in Community Programs: Purpose, Practice and

Directions for Research' Journal of Community Psychology, 33 1-10.

\section{Author Biographies}

*Evelyn Delgado was the Developer for the Royal Alberta Museum's Children Gallery. She has $16+$ years of working with children in science centers, museums, preschools and community art organizations. In the past 8 years her focus has shifted to developing exhibits and experiences in children's museums, libraries and other alternative learning institutions.

Contact: EvelynDelgadoBFA@gmail.com

** Jaclyn Kozak: With a background of Theatre from the University of Manitoba, Jaclyn has an abundance of experience in directing, writing, acting, and designing theatrical productions. Jaclyn has been committed to developing innovating and inclusive programming and interpretation for young learners using physical theatre, improvisational theatre games, clowning, and collective creation techniques the past 5 years at the Royal Alberta Museum's former location. Recently they presented at Grant MacEwan's Child Care Conference 2016, and Alberta Museum Association Annual Conference 2016.

Primary contact: jaclyn_kozak@hotmail.com/ ph.780-200-6010

**Natalie Charette is the Curatorial Assistant for the Royal Alberta Museum's Indigenous Studies department, where she has curated Indigenous-content exhibits for the museum's new galleries and manages the museum's Indigenous advisory panel. Natalie has a Master of Museum Studies degree from the University of Toronto and has a background in Canadian Art History.

Contact: Natalie.charette@gov.ab.ca or natalie.charette@gmail.com ph.780 720 8837

Royal Alberta Museum

12845-103A Avenue

Edmonton Alberta

T5N $0 \mathrm{M} 6$

Fax 7804546629 